\title{
The effectiveness of TOEFL app for final-year students of Marine and Fisheries Faculty Universitas Syiah Kuala, Indonesia
}

\author{
Riyan Maulana ${ }^{1}$ Irwan Irwan ${ }^{2 *}$, Cut Maila Hanum ${ }^{3}$, Mujiburrahman Mujiburrahman ${ }^{1}$ and Lidiana Lidiana ${ }^{1}$ \\ ${ }^{1}$ STMIK Indonesia Banda Aceh, Information System Department, Aceh-Indonesia \\ ${ }^{2}$ Department of Marine Sciences, Faculty of Marine and Fisheries, Universitas Syiah Kuala, Aceh- Indonesia \\ ${ }^{3}$ STIK Pante Kulu, Forestry Science Department, Aceh-Indonesia
}

\begin{abstract}
The paper reports the final-year students' needs of English and its effectiveness in joining TOEFL Class conducted by Academic of FKP using TOEF FKP application in learning process. There were about 45 final-year students in the academic year 2020-2021 as the primary objects of this research. The researcher is qualitative research and administered questionnaires and interviews to collect data and constructed as. The results found that the students need English skill to face challenges in the future for their career. It was also found that there was a high demand for TOEFL Certificate as a proof as English capacity, as a graduation requirement in the faculty and as a tool in order to work in international maritime industries in Aceh. Therefore, most of the students placed English skill as their highest priority. This application can facilitate the process of learning English in particular because it utilizes technological developments in this case the android application where they have been introduced since childhood to them at home. It concluded that the results of this investigation should be taken into account in developing teaching, learning materials, improving the TOEFL FKP app and its regulation for marine students.
\end{abstract}

\section{Introduction}

Education is a human attempt to develop and increase physical and spiritual capability based on the society and culture values especially for those who are studying in a higher university. Each student needs to perform well and gets good learning results especially in English. Moreover, to make it happens there are some variables such as motivation, teacher, etc to accomplish all that things and in this case in pandemic era learning tool based on android system is as one of the factors affecting students achievement in English skill that could assist the effectiveness of that process [1]. In this pandemic era a media for learning process especially TOEFL Class such as application should be available to conduct good academic process [2]. The Law of the Republic of Indonesia Number 20 of 2003 mentions that it is related to distance education where students are separated from educators and learning uses various learning sources including online media. [3].

As we know that TOEFL mastery is a must for someone who wants to complete their study in Syiah Kuala University as a requirement. Without a good TOEFL score, it is quite impossible for students to conduct final examination. Because English is as a requirement for final year students and now is pandemic era so it is would be better if there will be learning media such as an application to support TOEFL learning process either online or offline [4]. It means that the aim of learning media such as TOEFL FKP is to let the final year students enjoy the last learning process before completing thei ${ }^{2}$ r study in Syiah Kuala university. Clark said that at present time Internet use through mobile devices increasingly dominant, so e-learning will easily become mobile learning without special changes in content [5].

Therefore, it is deemed necessary to develop interactive multimedia as a learning medium [6]. Delphi argues that merging between mobile-based computing and e-learning will broaden access to resources, robust search capabilities, enrich interactions and support unrestricted access to space and time [7], [8]. In addition, Multimedia has an important role in learning, therefore it is deemed necessary to develop interactive multimedia as a learning medium [9].

Some previous research about using mobile app in learning already conducted by some researcher for example a research conducted by the Acehnese researcher from STMIK Indonesia Banda Aceh entitle An Android-Based Vocabulary Model for Autism showed that mobile app can improve students outcome after learning and many more advantages [10]. Based on the description of the problems above, the writer wants to see the quality of learning of students in mastering English through the use of mobile learning application to support teaching and learning activities, especially TOEFL for students as a support for the independent learning process during pandemic era.

\footnotetext{
${ }^{*}$ Corresponding author : irwan@unsyiah.ac.id
} 


\subsection{Research Question}

Based on the research background above. This study specifically aims to find answers about the following questions:

1. What are students' perceptions toward TOEFL FKP application in Marine and Fisheries Faculty, USK?

2. How are students' motivations toward TOEFL FKP application at Marine and Fisheries Faculty, USK?

\subsection{Research Significant}

Based on the research statement, this particular study aimed at finding out:

1. To know students' perceptions toward TOEFL FKP application in Marine and Fisheries Faculty, USK

2. To know students' motivations toward TOEFL FKP application at Marine and Fisheries Faculty, USK.

\section{Methodology}

\subsection{Research Design}

The method of this research is qualitative research. It is based on the research, there are focus; to exploring students perceptions toward the use of TOEFL FKP application by distributing questionnaire and interview to some final year students. This research focuses on descriptive qualitative method. Descriptive method has not purpose to test the certain hypothesis, but to describe some variable and condition naturally [11]. This research has purpose to look at the effectiveness of TOEFL FKP App for Final-Year Students of Marine Science Faculty Syiah Kuala University, Indonesia.

To prove the influence of the students' perception on TOEFL FKP and their motivation to learn, the researcher used the chi-square test and obtained the following results:

The calculation used to find out the percentage level of answer scores from each respondent is used a formula:

$$
P=\frac{f}{N} \times 100 \%
$$

Where, $P$ is Percentage of anwers; $f$ is Frequency of anwers; $\mathrm{N}$ is Total frequency.

Based on the results of the percentage value above, the effectiveness between students' perceptions suggested that the management of TOEFL FKP section would increase and ultimately affect learning performance because good responses from the questioners.

\subsection{Data Collection}

In this research, the researcher uses questionnaires in collecting data. According to Yusuf, questionnaire is an investigation carried out by sending a questionnaire to respondents who have been determined and after being filled out the questionnaire is returned to the researcher [12]. In addition, Deddy said that the questionnaire is data collection instruments that the most widely used in social research, whether qualitative or quantitative [13]. The purpose of questionnaire is to find out their mind, what they think or how they feel about something [14].

In this research, the researcher uses closed-ended questionnaire. The questionnaire consisted of ten questions that focused on students' perceptions and motivation of TOEFL FKP application. Moreover, to make it easier for students to fill, the questionnaire is prepared by using Indonesian. To distribute the data, the researcher made an electronic questionnaire in the form of a Google Form [15].

\subsection{Data Analysis}

In analysing data the researcher uses descriptive qualitative analysis based on Miles and Huberman Interactive models theory [16]. There are three main components, they are: reduction the data, presentation/display the data, verification or drawing conclusion.

\subsubsection{Population and Sample}

This part talks about the sample that is going to be chosen by the researcher. Research sample is a part of a subject that is going to be observed or analysed. The sample is partial or representative of the subject. The population of this study is 45 final-year students in the academic year 2020-2021. The researcher used purposive sampling technique in choosing sample for this study because purposive sampling is an effective way as a sampling technique for qualitative research.

According to Sugiyono purposive sampling technique is a type of non-probability sampling that is most effective when one needs to study a certain cultural domain with knowledgeable experts within and purposive sampling may also be used with both qualitative and quantitative re- search techniques.

\section{Results and Discussion}

Through a number of features and menu options in the application, the user can carry out a series of activities that are in accordance with the purpose of application development. Here are some menus and features provided in the application:

\subsection{Main Display}

The main display is the media interface for the menu to be selected, looks like the following picture 1. In Figure 1 above it can be explained that users can easily learn TOEFL based on the menus that have been arranged in such a way. They only need to click on one of the menu in the Home application view. 


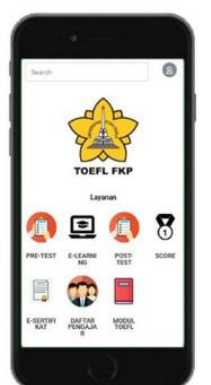

Fig. 1. Main Display

Table 1. Questionnaire Perceptions toward TOEFL FKP App.

\begin{tabular}{|c|c|c|c|c|}
\hline No. & Item & Option & Frequency & $\begin{array}{l}\text { Percentage } \\
(\%)\end{array}$ \\
\hline 1. & $\begin{array}{l}\text { I like to use the TOEFL } \\
\text { FKP application to } \\
\text { study }\end{array}$ & $\begin{array}{l}\text { Always } \\
\text { Often } \\
\text { Sometimes } \\
\text { Seldom } \\
\text { Never }\end{array}$ & $\begin{array}{l}0 \\
4 \\
5 \\
32 \\
4\end{array}$ & $\begin{array}{l}0 \\
8,9 \\
11,1 \\
71,1 \\
8,9\end{array}$ \\
\hline 2. & $\begin{array}{l}\text { Using the online } \\
\text { application like TOEFL } \\
\text { FKP is my style }\end{array}$ & $\begin{array}{l}\text { Always } \\
\text { Often } \\
\text { Sometimes } \\
\text { Seldom } \\
\text { Never }\end{array}$ & $\begin{array}{l}2 \\
10 \\
14 \\
11 \\
8\end{array}$ & $\begin{array}{l}4,4 \\
22,2 \\
31,1 \\
24,4 \\
17,8\end{array}$ \\
\hline 3. & $\begin{array}{l}\text { The TOEFL FKP } \\
\text { application provides } \\
\text { information/materials/q } \\
\text { uestions that are easy to } \\
\text { understand }\end{array}$ & $\begin{array}{l}\text { Always } \\
\text { Often } \\
\text { Sometimes } \\
\text { Seldom } \\
\text { Never }\end{array}$ & $\begin{array}{l}5 \\
4 \\
17 \\
17 \\
2\end{array}$ & $\begin{array}{l}11,1 \\
8,9 \\
37,8 \\
37,8 \\
4,4\end{array}$ \\
\hline 4. & $\begin{array}{l}\text { The TOEFL FKP } \\
\text { application allows me } \\
\text { to study whenever and } \\
\text { wherever I am }\end{array}$ & $\begin{array}{l}\text { Always } \\
\text { Often } \\
\text { Sometimes } \\
\text { Seldom } \\
\text { Never } \\
\end{array}$ & $\begin{array}{l}5 \\
4 \\
17 \\
14 \\
5\end{array}$ & $\begin{array}{l}11,1 \\
8,9 \\
37,8 \\
31,1 \\
11,1\end{array}$ \\
\hline 5. & $\begin{array}{l}\text { The TOEFL FKP } \\
\text { application facilitates } \\
\text { the learning needs of } \\
\text { me }\end{array}$ & \begin{tabular}{|l} 
Always \\
Often \\
Sometimes \\
Seldom \\
Never \\
\end{tabular} & $\begin{array}{l}3 \\
11 \\
20 \\
9 \\
2\end{array}$ & $\begin{array}{l}6,7 \\
24,4 \\
44,4 \\
20,1 \\
4,4 \\
\end{array}$ \\
\hline 6. & $\begin{array}{l}\text { I intend to use the } \\
\text { TOEFL FKP } \\
\text { application for future }\end{array}$ & $\begin{array}{l}\text { Always } \\
\text { Often } \\
\text { Sometimes } \\
\text { Seldom } \\
\text { Never }\end{array}$ & $\begin{array}{l}4 \\
12 \\
12 \\
10 \\
7\end{array}$ & $\begin{array}{l}8,9 \\
26,7 \\
26,7 \\
22,2 \\
15,6\end{array}$ \\
\hline 7. & $\begin{array}{l}\text { The TOEFL FKP } \\
\text { application is easy to } \\
\text { use }\end{array}$ & \begin{tabular}{|l} 
Always \\
Often \\
Sometimes \\
Seldom \\
Never \\
\end{tabular} & $\begin{array}{l}2 \\
10 \\
26 \\
5 \\
2 \\
\end{array}$ & $\begin{array}{l}4,4 \\
22,2 \\
57,8 \\
11,1 \\
4,4\end{array}$ \\
\hline 8. & $\begin{array}{l}\text { I use the TOEFL FKP } \\
\text { app because it's fun }\end{array}$ & \begin{tabular}{|l} 
Always \\
Often \\
Sometimes \\
Seldom \\
Never \\
\end{tabular} & $\begin{array}{l}6 \\
13 \\
8 \\
9 \\
9 \\
\end{array}$ & $\begin{array}{l}13,3 \\
28,9 \\
17,8 \\
20 \\
20\end{array}$ \\
\hline 9. & $\begin{array}{l}\text { I believe that using the } \\
\text { TOEFL FKP } \\
\text { application will } \\
\text { improve my learning } \\
\text { outcomes. }\end{array}$ & \begin{tabular}{|l} 
Always \\
Often \\
Sometimes \\
Seldom \\
Never
\end{tabular} & $\begin{array}{l}6 \\
7 \\
9 \\
12 \\
11\end{array}$ & $\begin{array}{l}13,3 \\
15,6 \\
20 \\
26,7 \\
24,4\end{array}$ \\
\hline 10 & $\begin{array}{l}\text { I am used to using new } \\
\text { technology like the } \\
\text { TOEFL FKP app }\end{array}$ & $\begin{array}{l}\text { Always } \\
\text { Often } \\
\text { Sometimes }\end{array}$ & $\begin{array}{l}6 \\
7 \\
9\end{array}$ & $\begin{array}{l}13,3 \\
15,6 \\
20 \\
26,7\end{array}$ \\
\hline
\end{tabular}

\begin{tabular}{|l|l|l|l|l|}
\hline & $\begin{array}{l}\text { Seldom } \\
\text { Never }\end{array}$ & 12 & 24,4 \\
\hline
\end{tabular}

\section{Conclusion}

Briefly, this application has been designed to be used specifically for students especially for TOEFL subject and has been tested using descriptive statistical methods with different calculation models and has run well, and can then be installed on an Android-based mobile phone.

This application can facilitate the process of learning English in particular because it utilizes technological developments in this case the android application where they have been introduced since childhood to them at home. So hopefully the language learning process for them can attract attention by displaying features and menus in the application.

From the results and the previous discussion, it can be concluded several things related to the application of the TOEFL FKP as follows;

a. The application of TOEFL FKP received a positive response in several ways, namely the practicality of sharing material, independent learning, and saving time and costs in the learning process.

b. Students still cannot have strong motivation to learn if they have to study alone without face to face with the lecturer.

c. Students cannot understand easily if they have to do self-study of the material provided.

d. Some students have not been able to enjoy and accept TOEFL FKP, since they used to the face-to-face model that has been done so far.

Finally, this application should be taken into account in developing teaching, learning materials, improving the TOEFL FKP app and its regulation for marine student.

\section{References}

1. M, Deddy. Qualitative Research Methods. Bandung. PT Teen Rosdakarya. (2003)

2. K, Nyiri. Towards a philosophy of learning, Wireless and Mobile Technologies in Education, IEEE International Workshop, 121,124. (2002)

3. Kaur, M. Blended learning - its challenges and future. Procedia - Social and Behavioral Sciences, 612-617. (2003)

4. J, Chen. The Effectiveness of Peer Assessment in EFL Blended Learning Environments. Paper presented at the 2021 2nd International Conference on Computers, Information Processing and Advanced Education. (2021).

5. J. W, Creswell,.Research design: qualitative, quantitative, and mixed approaches. Yogjakarta: PT PustakaPelajar. (2010).

6. A, Fergina, Prancisca, S., Ismiyani, N., Suparjan, S., Barella, Y., \&Linarsih, A. The 
Training of Digital Media Utilization in English Online Learning for Students and Alumni in Pontianak. JPKM (JurnalPengabdianKepadaMasyarakat) UNTAN, 4(1), 9-15. (2021).

7. Arifin, Z. (2012). Penelitian Pendidikan. Bandung: PT. RemajaRosdakarya.

8. S. E, Smaldino, Lowther, D. L., \& Mims, C. Instructional Technology and Media for Learning. (2019).

9. D, Bandi. Learning for children with special needs (in inclusive education settings) Prints I. Bandung: RafikaAditama. Combined. Jakarta :prenadamedia group. (2006).

10. R Maulana, Bahruni. An Android-Based Vocabulary Model For Autism. International Journal of Information Systems \& Technology. (2019)

11. Sugiyono. Quantitative, Qualitative and $R \& D$ Research Methods. Bandung: Afabeta. (2011).

12. A. Muri Yusuf..Quantitative, Qualitative \& Research Methods. (2014)

13. B. M, Miles and M Huberman. Qualitative Data Analysis Source Book About New Methods. Jakarta: UIP. (1992)

14. C Quinn., M-Learning: Mobile, Wireless, In Your-Pocket Learning, Retrieved October 28, 2021, from http://linezone.com: http://linezone.com. (2014).

15. M. M. E. I, Bali \&Holilah, N. The Role of Foster Caregivers in the Effectiveness of Online Learning in Pesantren. EdukasiIslami: JurnalPendidikan Islam, 10(01), 339-362. (2021).

16. Alam, M. M., Ahmad, N., Naveed, Q. N., Patel, A., Abohashrh, M., \&Khaleel, M. A. Elearning services to achieve sustainable learning and academic performance: An empirical study. Sustainability, 13(5), 2653. (2021) 